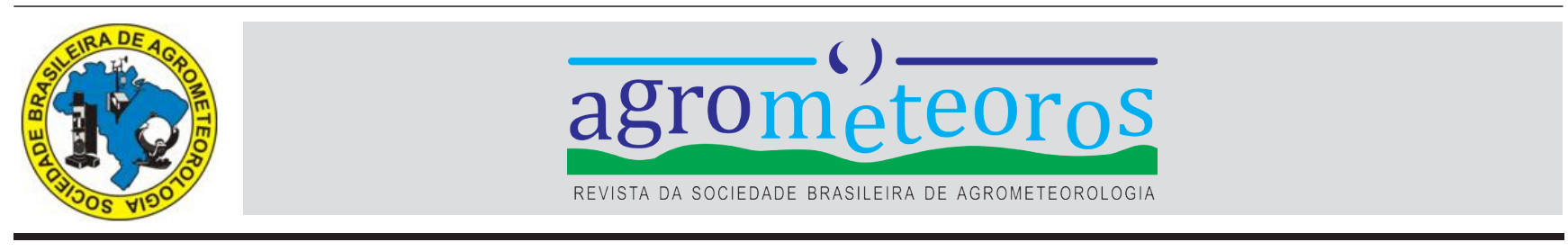

\title{
Irrigated rice sowing periods based on simulated grain yield
}

\author{
Silvio Steinmetz ${ }^{(1)}{ }^{*}$, Santiago Vianna Cuadra ${ }^{1}$, Ivan Rodrigues de Almeida ${ }^{1}$, Nereu Augusto Streck ${ }^{2}$, Alencar Júnior Zanon ${ }^{2}$, Gio- \\ vana Ghislene Ribas ${ }^{2}$, Michel Rocha da Silva ${ }^{2}$, Rômulo Pulcinelli Benedetti ${ }^{2}$, Jossana Ceolin Cera ${ }^{3}$, Silvando Carlos da Silva ${ }^{4}$ and \\ Alexandre Bryan Heinemann ${ }^{4}$ \\ ${ }^{1}$ Embrapa Clima Temperado. Rodovia BR 392 km 78, Cx. Postal 403, CEP 96.010-971 Pelotas, RS, Brazil. \\ E-mails: silvio.steinmetz@embrapa.br, santiago.cuadra@embrapa.br and ivan.almeida@embrapa.br \\ ${ }^{2}$ Universidade Federal de Santa Maria (UFSM), Departamento de Fitotecnia, Centro de Ciências Rurais (CCR). Avenida Roraima, 1000, Bairro Camobi, CEP \\ 97105-900 Santa Maria, RS, Brazil. \\ E-mails: nereustreck2@yahoo.com.br, alencarzanon@hotmail.com, giovana.ghisleni@hotmail.com, michelrs@live.com and romuluspb@gmail.com \\ ${ }^{3}$ Instituto Rio Grandense do Arroz (IRGA), Estação Experimental do Arroz (EEA). Avenida Bonifácio Carvalho Bernardes, 1494 - Vila Carlos Antonio Wilk- \\ ens, CEP 94930-030 Cachoeirinha, RS, Brazil. E-mail: jossana.cera@gmail.com \\ ${ }^{4}$ Embrapa Arroz e Feijão. Rodovia GO 462, km 12, Fazenda Capivara, Zona Rural Caixa Postal 179, CEP 75375-000 Santo Antônio de Goiás, GO, Brazil. \\ E-mails: silvando.silva@embrapa.br and alexandre.heinemann@embrapa.br \\ ${ }^{(*)}$ Corresponding author.
}

\section{ARTICLE INFO}

\section{Article history:}

Received 30 January 2019

Accepted 11 March 2020

\section{Index terms:}

Oryza sativa L.

crop model

climate

risk zoning

\section{ABSTRACT}

This study aimed to establish the sowing periods with lower climatic risk for irrigated rice cultivation in the State of Rio Grande do Sul, Brazil, using the grain yield simulated by the SimulArroz which is an eco-physiological model based in processes that also simulates the development and the growth of the crop. The simulated grain yields were normalized for each of the four groups of cultivars, referenced as Relative Yield (YRel), considering the values of Reference Yield (YRef). The YRef considered was equal to the 80 percentile for the cultivars of groups 1 and 2 (Very short and Short cycle, respectively), and to the 90 percentile, for the cultivars of groups 3 and 4 (Medium and Long cycle, respectively). A successful year was when the YRel value was equal to or greater than $60 \%$ of YRef. These years were used to classify the climatic risk levels of $20 \%$ (80\% success), $30 \%$ ( $70 \%$ success) and $40 \%$ ( $60 \%$ success). The preferential sowing periods for the four cultivar groups, at three levels of climatic risk, were established for all counties of the State of Rio Grande do Sul. The results indicated that the beginning of sowing occurs, depending on the group of cultivars, on September 1st or September 11th. On the other hand, the final sowing date varies with the group of cultivars and the level of risk involved, being December 20th the last sowing date for group 1 (Very short cycle). It is concluded that the SimulArroz model is appropriate to define the sowing periods of irrigated rice in Rio Grande do Sul considering grain yield, cycle of the cultivars and level of climatic risk. 


\section{Introduction}

The State of Rio Grande do Sul (RS) is the largest producer of irrigated rice (Oryza sativa 1.) in Brazil. In the 2016/2017 and 2017/2018 crop seasons, the State contributed with approximately $70 \%$ of the national rice production. Despite of high grain yield levels, around $7.9 \mathrm{t} \mathrm{ha}^{-1}$ (Conab, 2018), there is variability over the years due to climate. The climatic influence is due either to site-specific events such as hail, heavy rain (floods) and windstorms, or more generalized ones, as waves of cold, heat or consecutive days of rain, interfering in the availability of solar radiation.

The low air temperature occurrence $\left(\leq 15^{\circ} \mathrm{C}\right)$ during booting and flowering stages and/or low availability of solar radiation during reproductive growth stages are two meteorological elements that, in some years, affect the crop grain yield (Terres; Galli, 1985; Cruz, 2006; Steinmetz, Almeida, 2012; Steinmetz et al., 2013). High air temperatures during either the daytime $\left(\geq 35^{\circ} \mathrm{C}\right)$ or at night $\left(\geq 25^{\circ} \mathrm{C}\right)$, also affect the grain yield (Matsui et al., 2001; Peng et al., 2004; Prasad et al., 2006).

Air temperature also influences the speed of the crop development. In general, thermal time or the accumulation of degree-day (GD) is used as indicator to predict when a particular plant stage development will occur. In colder regions and/or early sowings, the rice crop takes longer to develop. On the other hand, in the warmer regions and/ or intermediate or late sowings, the development is faster (Steinmetz et al., 2010; 2015). Besides that, depending on the sowing date and the cultivar sensitivity, the photoperiod can affect the crop cycle (Streck et al., 2006).

Sowing date is one of the management practices that play a major role in reducing the risk due to climate by increasing the chances that critical phases of the crop avoid the adverse meteorological elements and/or match the favorable ones. Field results of different sowing dates prove this hypothesis, and indicate that yield levels are also influenced by the cycle of the cultivars (Menezes et al., 2003; Mariot et al., 2007; Steinmetz et al., 2009).

The previous studies related to agroclimatic zoning defined the best sowing periods based on soil temperature $\left(\mathrm{Ts} \geq 20^{\circ} \mathrm{C}\right.$ at $5 \mathrm{~cm}$ depth), to indicate the beginning of sowing, on the risk of occurrence of low temperatures $\left(\mathrm{Tn} \leq 15^{\circ} \mathrm{C}\right)$ during booting and flowering, and on solar radiation availability during the reproductive growth stages, as well as grain yield data from sowing dates experiments (Steinmetz et al., 2007).

Sowing periods established by the Agricultural Zoning of Climatic Risk (ZARC) has been used, with success, since the 1995/1996 crop season, not only for reimbursement of "Proagro" (agricultural activity insurance program) of several crops, but also as an instrument of public policies by the Ministry of Agriculture, Livestock and Food Supply-MAPA (Rossetti, 2001). The pioneer studies of sowing periods, which gave methodological support for the implementation of the ZARC, were developed with the upland rice in the 1980's (Steinmetz \& Silva, 2017).

Process-based models are modern tools that, among other applications, can be used to determine sowing periods with lower climatic risks, as indicated in the results of Amaral et al. (2011) and Paixão et al. (2014). However, there is the need of crop model calibration and validation for a given region. SimulArroz (www.ufsm.br/simularroz/), an eco-physiological model based in processes that simulates irrigated rice development, growth and grain yield based on climate, cultivar and management data set. From a set of processes, or subroutines, the program estimates, among others, the following variables: the main stages of the plant development, dry matter accumulation, spikelet sterility index, potential and actual grain yield. The grain yield can be simulated either for a given cultivar or for groups of cultivars (Rosa et al., 2015; Ribas et al., 2016; 2017).

The present study is considered as pioneer because it established the best sowing periods based on crop modeling grain yield estimates and on different levels of climatic risk. This type of information is useful for governmental decrees of MAPA and it can be used for issues related to the agricultural insurance policies, either from the Government (Proagro and Proagro Mais) or private companies.

This study aimed to establish the best sowing periods for irrigated rice cultivation in the State of Rio Grande do Sul, based on grain yield estimated by the SimulArroz model.

\section{Material and Methods}

The SimulArroz model (Rosa et al., 2015; Ribas et al., 201 and 2017), and the POWER/NASA (POWER/NASA, 2018) daily climate dataset, for a 30 years period (1986-2015) were used to determine the sowing periods with lower climatic risk. The climate variables used to run SimulArroz were the maximum and minimum air temperature and solar radiation. Simulations were done for sowing dates involving the period from September $1^{\text {st }}$ to December $31^{\text {th }}$, using 10-day period intervals, for four groups of cultivars, namely: group 1: Very short cycle (MP) - up to 105 days to maturity; group 2: Short cycle $(\mathrm{P})$ - maturation between 106 and 120 days; group 3: Medium cycle (M) - maturation between 121 and 135 days and group 4: Long cycle (T) - maturation between 136 and 150 days. The cycles of the cultivars of these groups are those listed in SISZARC (Brasil, 2018b) which, in general, coincide with those indicated by the South-Brazilian Society of Irrigated Rice (Sosbai, 2018).

Grain yield data estimated by SimulArroz model were 
normalized for each group of cultivars, considering the values of Relative Yield (YRel), given by the relation between the yield obtained for each of the simulations (different locations, years and sowing dates) and the Reference Yield (YRef) - equivalent to the values of high yield obtained currently by farmers that use high level of technology (Rosa et al., 2015). The YRef considered were equal to the 80 yield percentile (considering all locations and years), for the cultivars of groups 1 and 2, and to the 90 yield percentile, for the cultivars of groups 3 and 4 . The 80 and 90 yield percentiles were selected in order to have sowing periods compatible with those of previous studies (Steinmetz et al., 1996 and 2007).

The values of YRel were used to indicate the areas suitable for the cultivation of irrigated rice in low-risk conditions. The years with success were considered when the YRel values were equal to or greater than $60 \%$ compared to YRef. This value is referred to as "Threshold".

The climatic risk or success levels, considered as the frequency of years in which the YRel was equal to or greater than $60 \%$ of YRef, were used for the classification of the distinct counties, being classified for risks of $20 \%$ ( $80 \%$ success), $30 \%$ (70\% success) and $40 \%$ (60\% success).

The reference yields (YRef) used for groups 2, 3 and 4 in the percentile indicated previously were, respectively, $4,699 \mathrm{~kg} \mathrm{ha}^{-1}, 7,428 \mathrm{~kg} \mathrm{ha}^{-1}$ and 7,996 $\mathrm{kg} \mathrm{ha}^{-1}$. The limit values for the calculation of loss frequencies were considered as $60 \%$ of the YRefs, i.e. when the simulated yield is lower than the threshold one, it was considered as a year of loss.

The ten-day sowing periods, for the groups 2, 3 and 4 and three levels of risk have been defined by the criteria previously indicated. The sowing periods for the group 1 began 10 days later and ended also 10 days later than the group 2. This criterion was used because the grain yield simulated for this group was less consistent than for the other three groups when compared to the results indicated by Rosa et al. (2015).

The counties were considered suitable for a given sowing period if at least $20 \%$ of their territory were in agreement with the previously indicated criteria.

The maps were generated using the procedure indicated as follow. As the sowing date simulations were performed on the climate database that is spatially organized under a regular grid, the yield results between the points of this grid were interpolated by the 'ordinary kriging' method, providing images that were classified to indicate potential yield levels according to each sowing date.

Combined into groups of risk and groups of cultivars, the synthesis of the images produced thirteen common sowing periods, subdivided into two initial dates (September 1 and 11) and different ending dates denoting, for each municipality, the largest or smallest duration of the sowing period.
All digital processing of these procedures were conducted in GIS environment (Geographic Information Systems), process simulator (SimulArroz) and computational tools for validation of agricultural scenarios (Micura - Metrics and Information for Conservation and Use of Resources in Agriculture) developed by Embrapa Agricultural Informatics (Uratsuka \& Nakai, 2017).

Sowing periods were established for all municipalities of the State of Rio Grande do Sul suitable for irrigated rice cultivation. However, in each map, the six main producing regions are identified according to the criteria used by the Rio Grande do Sul State Rice Institute (IRGA).

In the decrees of ZARC - MAPA (Brasil, 2018a), each ten-day period is identified by a number, going from 1 (1-10 January) up to 36 (21-31 December). In order to simplify the understanding, in this study it is shown only an example indicating the starting and ending dates of the recommended sowing periods (Table 2), identifying if the county belongs to any of the six rice-producing regions of Rio Grande do Sul (Menezes et al., 2012).

The soil types 1 (sandy soils), 2 (medium texture soils) and 3 (clay soils) were assumed to be suitable for the cultivation of irrigated rice in the State if observed the specifications and recommendations indicated in the Normative Statement $\mathrm{n}^{\mathrm{o}} 2$, of October $9^{\text {th }} 2008$ of MAPA (Brasil, 2008). It should be emphasized that, for irrigated rice, the type of soil is not as limiting as for upland crops. The reason is that in the irrigated rice, the crop is maintained with a water layer (flooded) for almost its entire biological cycle. Thus, the crop does not present risk of water deficit, as occurs with the upland rice and the other non-irrigated crops, and the farmer is responsible for keeping the crop without the occurrence of water deficit.

Permanent preservation areas are not indicated for rice cultivation, according to the Law number 12,651 from May 25 2012 (Brasil, 2012).

\section{Results and Discussion}

The results indicate that the best sowing periods vary depending on the cycle of cultivars, rice-producing region (county) and climatic risk level considered (Table 1 and Figures 1, 2 and 3). Table 1 shows an illustration of the sowing periods most frequently observed in most counties in the State of Rio Grande do Sul (RS) indicated in Figures 1,2 and 3 .

In general, the sowing for the cultivars of the groups 2 , 3 and 4 , considering the risk levels of 20,30 and $40 \%$, can be initiated in the first 10-day period of September, i.e. in the period from 1 to 10 of this month (ten-day period 25). Contrasting with the other three groups, the beginning of sowing for the cultivars of group 1, in the three risk levels, must be retarded in about 10 days, which corresponds to 
Table 1. Most frequent sowing periods, for ten-day intervals, for four groups (Very short-1, Short-2, Medium-3 and Long-4 cycles) of irrigated rice cultivars and three levels (20,30 and 40\%) of climatic risk.

\begin{tabular}{|c|c|c|c|c|c|c|c|c|c|c|c|c|c|}
\hline \multirow{3}{*}{$\begin{array}{l}\text { Groups of } \\
\text { cultivars }\end{array}$} & \multirow{3}{*}{$\begin{array}{c}\text { Levels } \\
\text { of risk } \\
(\%)\end{array}$} & \multirow[b]{2}{*}{1 Sep } & \multirow[b]{2}{*}{2 Sep } & \multirow[b]{2}{*}{3 Sep } & \multicolumn{6}{|c|}{ Sowing periods (ten-day periods) } & \multirow[b]{2}{*}{$1 \mathrm{Dec}$} & \multirow[b]{2}{*}{$2 \mathrm{Dec}$} & \multirow[b]{2}{*}{$3 \mathrm{Dec}$} \\
\hline & & & & & $10 c t$ & 2 Oct & 3 Oct & $1 \mathrm{Nov}$ & $2 \mathrm{Nov}$ & $3 \mathrm{Nov}$ & & & \\
\hline & & 25 & 26 & 27 & 28 & 29 & 30 & 31 & 32 & 33 & 34 & 35 & 36 \\
\hline 1 & 20 & & $x$ & $x$ & X & X & $x$ & X & $x$ & X & X & $X$ & \\
\hline 2 & 20 & $x$ & $x$ & $x$ & $x$ & $x$ & $x$ & $x$ & $x$ & $x$ & $x$ & & \\
\hline 3 & 20 & $x$ & $x$ & $x$ & $x$ & $x$ & $x$ & $x$ & $x$ & $\mathrm{x}$ & & & \\
\hline 4 & 20 & $x$ & $x$ & $x$ & $x$ & $x$ & $x$ & $x$ & $x$ & & & & \\
\hline 1 & 30 & & $x$ & $X$ & $X$ & $X$ & $X$ & $X$ & $X$ & $X$ & $x$ & $X$ & \\
\hline 2 & 30 & $x$ & $x$ & $x$ & $x$ & $x$ & $x$ & $x$ & $x$ & $x$ & $x$ & & \\
\hline 3 & 30 & $x$ & $x$ & $x$ & $x$ & $x$ & $x$ & $x$ & $x$ & $X$ & & & \\
\hline 4 & 30 & $x$ & $x$ & $X$ & $x$ & $x$ & $x$ & $x$ & $X$ & & & & \\
\hline 1 & 40 & & $X$ & $X$ & $x$ & $X$ & $x$ & $x$ & $x$ & $X$ & $X$ & $X$ & \\
\hline 2 & 40 & $x$ & $x$ & $x$ & $x$ & $x$ & $x$ & $x$ & $X$ & $X$ & $x$ & & \\
\hline 3 & 40 & $x$ & $x$ & $x$ & $x$ & $x$ & $x$ & $x$ & $x$ & $x$ & & & \\
\hline 4 & 40 & $x$ & $x$ & $x$ & $x$ & $x$ & $x$ & $x$ & $x$ & & & & \\
\hline
\end{tabular}

the period from 11 to 20 September (ten-day period 26).

On the other hand, the end of the sowing period varies with cultivars cycle. Thus, for the risk level of $30 \%$, for example, the latest ten-day periods recommended are the 35 (11-20 Dec), 34 (1-10 Dec), 33 (21-30 Nov) and 32 (11-20 Nov), respectively, for groups 1, 2, 3 and 4 .

An example of the recommended sowing periods, by county, considering the risk level of $20 \%$, and the indication of some counties belonging to rice regions, according to the State Rice Institute (IRGA), is featured in the Table 2. Thus, for the county of Alegrete, which belongs to the "Fronteira Oeste" region (FO), the sowing periods extend from 11 September to 20 December, 01 September to 10 December, 01 September to 30 November and from 01 September to 20 November, respectively, for the cultivar groups 1, 2, 3 and 4 .

The anticipation of the final ten-day sowing periods for the cultivars of groups 2, 3 and 4, indicated in Tables 1 and 2 and in Figures 1, 2 and 3, occurs, basically, for two reasons. The first is that the risk of occurrence of minimum air temperatures that can affect the rice yield $\left(\mathrm{Tn} \leq 15^{\circ} \mathrm{C}\right)$ increases after the second ten-day period of March (Steinmetz et al., 1996; Cruz, 2006; Steinmetz; Almeida, 2012).

The second reason is that the availability of solar radiation, which is higher in December, begins to decrease gradually from the end of January (Steinmetz et al., 1996; Cruz, 2006). These two variables interfere in the crop grain yield and, as a consequence, the relative yield (YRel) simulated by SimulArroz stays below the threshold line of $60 \%$. Decreases in grain yield when sowings are carried out beyond a certain period were also obtained in field experiments (Slaton et al., 2003; Mariot et al., 2005, 2007; Steinmetz et al., 2009).
Table 2. Example of sowing periods for four groups of cultivars in the counties of the State of Rio Grande do Sul, considering the level of risk of $20 \%$. The municipalities that belong to the six rice producing regions are identified as follows: 1-"Fronteira Oeste" (FO); 2-“Campanha" (C); 3-"Depressão Central” (DC); 4-"Planície Costeira Interna" (PCI); 5-"Planície Costeira Externa" (PCE); 6-"Zona Sul" (ZS). The informations for other counties are available in Steinmetz et al. (2018).

\begin{tabular}{|c|c|c|c|c|}
\hline \multirow{2}{*}{ Counties } & \multirow{2}{*}{$\begin{array}{l}\text { IRGA's } \\
\text { Rice } \\
\text { Regions }\end{array}$} & \multicolumn{3}{|c|}{ Climatic risk of $20 \%$ - Groups of cultivars - Sowing periods } \\
\hline & & Very Short (G1) & Short (G2) & Medium (G3) \\
\hline 1 - Aceguá & $\mathrm{C}$ & 11set a 20dez & 01 set a $10 \mathrm{dez}$ & 01set a 30nov 01 set a 10nov. \\
\hline 2.-Água Santa. & -... & 11set a 20dez. & 01set a 10dez. & 01set a 30nov 01 3 set a 20nov. \\
\hline 3 - Agudo & DC & 11 set a 20 dez & 01 set a $10 \mathrm{dez}$ & 01set a 30nov 01 set a 20nov. \\
\hline 4. Ajuricaba & -... & 11set a 20dez & 01 set a $10 \mathrm{dez}$ & 01 set a 30nov 01 set a 20nov. \\
\hline 5 -Alecrim & 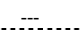 & 11 set a 20 dez & 01 set a 10dez & 01set a 30nov 01 set a 20nov. \\
\hline 6-Alegrete & FO & 11 set a $20 \mathrm{dez}$ & 01 set a $10 \mathrm{dez}$ & 01set a 30nov 01set a 20nov \\
\hline 7-Alegria & $\ldots$ & 11 set a $20 \mathrm{dez}$ & 01 set a $10 \mathrm{dez}$ & 01 set a 30 nov 01 set a 20 nov \\
\hline $\begin{array}{l}\text { 8-Aimirante } \\
\text { Tamandaré do Sul }\end{array}$ & -- & 11set a $20 \mathrm{dez}$ & 01 set a $10 \mathrm{dez}$ & 01 set a 30nov 01 set a 20nov \\
\hline 9 - Alpestre & -.-. & 11 set a 20 dez & 01 set a $10 \mathrm{dez}$ & 01set a 30nov 01 set a 20nov. \\
\hline 10 - Alto Alegre & $\ldots$ & 11 set a 20dez & 01 set a $10 \mathrm{dez}$ & 01 set a 30nov 01 set a 20nov \\
\hline 11 -Alto Feliz. & $\therefore .$. & 11set a 10dez. & 01 set a $10 \mathrm{dez}$ & 01set a 30nov 01 01set a 20nov. \\
\hline $\begin{array}{l}12 \text { - Alvorada } \\
13 \text { - Amaral }\end{array}$ & PCE. & 11set a 10dez. & 01 set a 10dez & 01set a 30nov 01 set a 20nov. \\
\hline Ferrador & PCI & 11 set a 20dez & 01 set a $10 \mathrm{dez}$ & 01set a 30 nov 01 set a 20 nov \\
\hline Sul Ametista do & $\ldots$ & 11 set a $20 \mathrm{dez}$ & 01 set a $10 \mathrm{dez}$ & 01 set a 30nov 01 set a 20nov \\
\hline $\begin{array}{l}15-\text { André da } \\
\text { Rocha }\end{array}$ & $\therefore-$ & 11set a 20dez & 01 set a 10 dez & 01 set a 30nov 01set a 20nov. \\
\hline 16 - Anta Gorda & -- & 11set a 20dez. & 01 set a $10 \mathrm{dez}$ & 01set a 30nov 01 01 set a 20nov. \\
\hline 17 - Antônio Prado & --- & 11 set a $10 \mathrm{dez}$ & 01 set a $10 \mathrm{dez}$ & 01set a 30nov 01set a 20nov \\
\hline
\end{tabular}

The sowing periods, for the four groups of cultivars, considering risk levels of $20 \%, 30 \%$ and $40 \%$ are represented in maps, respectively, in the Figures 1, 2 and 3.

Taking the Figure $1 \mathrm{~b}$ (group 2, risk of 20\%) as an example, the predominant and longer period, in most counties (dark blue), goes from 01 September (ten-day period 25) to 10 December (ten-day period 34). On the other hand, the anticipation of the final period of sowing is represented by lighter tones of blue and beige is concentrated in the counties located in the "Planície Costeira Externa" (PCE). It 
Figure 1. Sowing periods for the climatic risk of $20 \%$ and cultivars of groups 1 Very short (a), 2 - Short (b), 3 - Medium (c) and 4 - Long (d) of irrigated rice in the different counties and riceproducing regions of the State of Rio Grande do Sul.

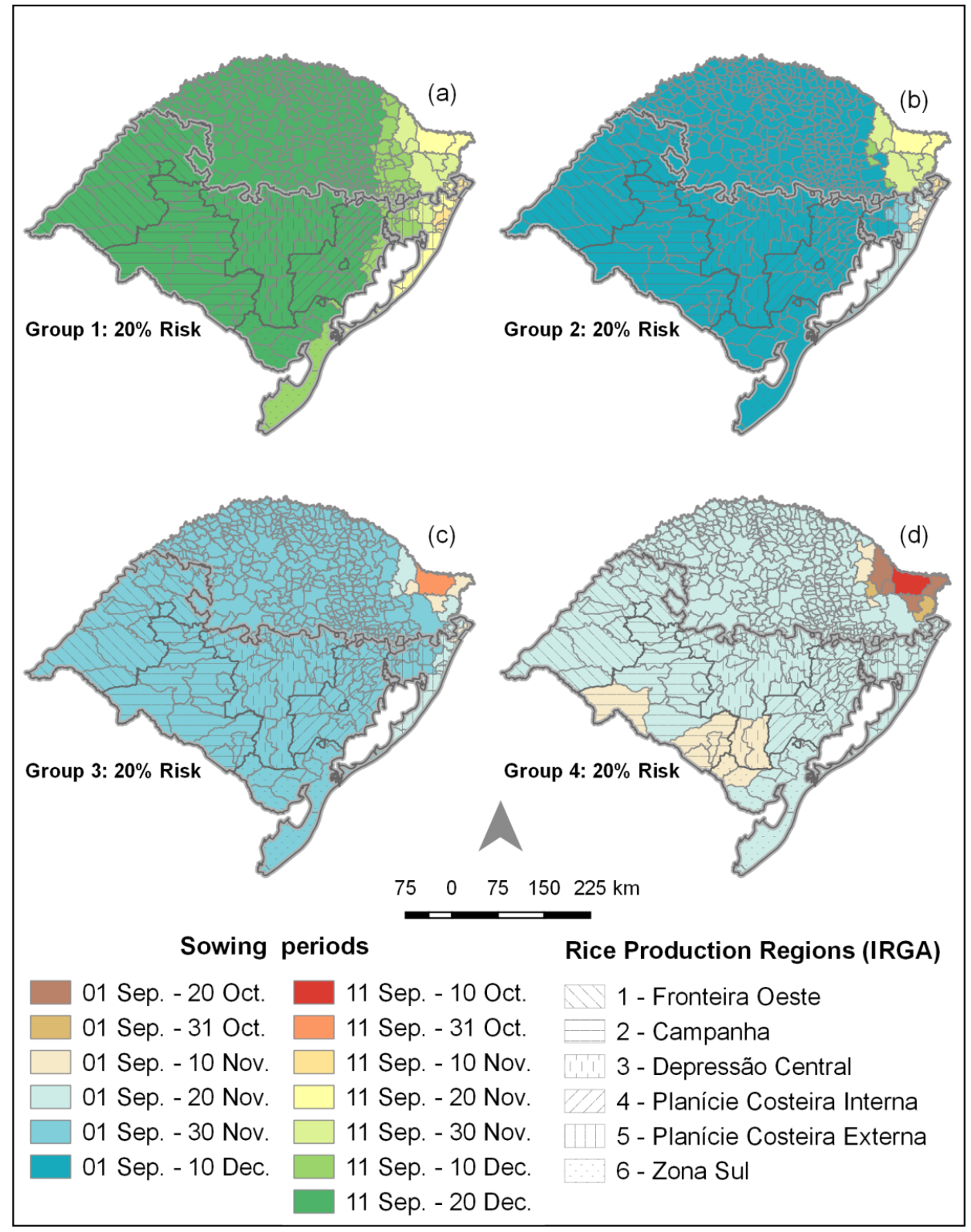

is likely that this anticipation is caused by the influence of the higher risk of low temperatures harmful to rice and lower solar radiation availability in these areas (Mota, 1995; Steinmetz et al., 2005; Wrege et al., 2011).

The areas in green tones and yellow, in the northeastern region of the State, indicate different final sowing periods in these areas (Figure 1b). However, it should be considered that, in this region of the State, the beginning of sowing occurs later, i.e. on September 11.

When analyzing the results for the cultivars of group 4 , with risk of $20 \%$ (Figure $1 \mathrm{~d}$ ), the predominant sowing period (light blue) goes from 01 September (ten-day period $25)$ to 20 November (10-day period 32) and extend for almost all State. The anticipation of the final sowing period to 10 November (ten-day period 31), which occurs in some counties of the regions "Campanha", "Depressão Central" and "Zona Sul", is probably associated with higher risk of cold for later sowings (Steinmetz et al., 2005).

Anticipations even more accentuated in the final sowing period, until 20 October (ten-day period 29), observed in some counties in the northeast region of the State (Figure 1d), also due to the increased in the risk of cold, being that area considered as unsuitable for irrigated rice cultivation in previous climatic zoning (Steinmetz et al., 2005; 2007).

The analysis of Figure 2 (risk of 30\%) indicates that the predominant and longer period, in most counties goes from 11 September to 10 December (dark green) for group 1 (Figure 2a), from 01 September to 10 December (dark blue) for group 2 (Figure 2b), from 01 September to 30 November (light blue) for the group 3 (Figure $2 \mathrm{c}$ ) and from 01 September to 20 November (lighter blue) for the group 4 (Figure 2d).

The behavior of the sowing periods for the risk level 
Figure 2. Sowing periods for the climatic risk of $30 \%$ and cultivars of groups 1 3 - Medium (c) and 4 - Long (d) of irrigated rice in the different counties and riceproducing regions of the State of Rio Grande do Sul. Very short (a), 2 - Short (b),

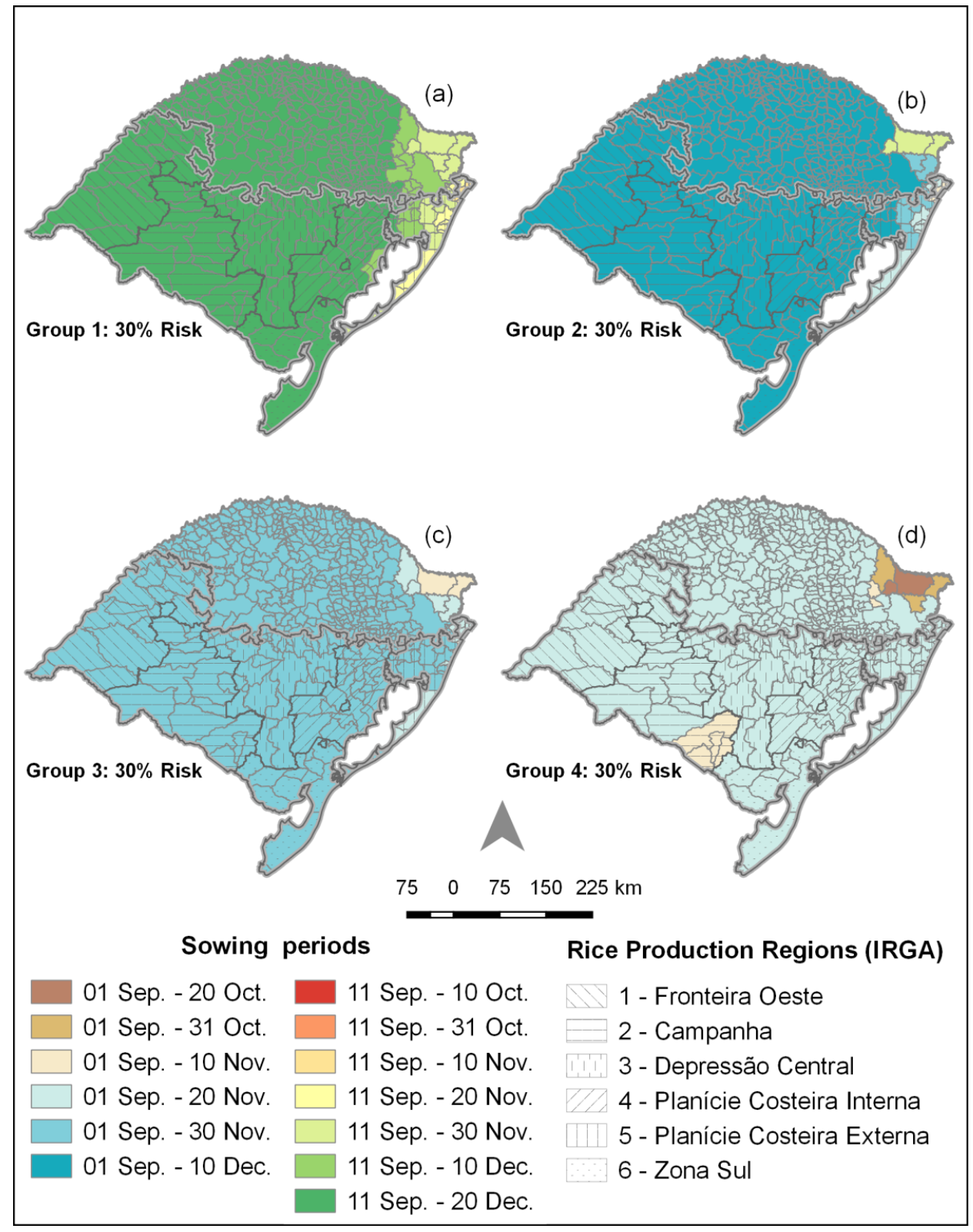

of $40 \%$ (Figure 3 ) is similar to those with risk level of $20 \%$ and $30 \%$.

The anticipation of the final period of sowing, at the risk levels of $30 \%$ and $40 \%$, for the four groups of cultivars, occurs mainly in the counties located in the "Planície Costeira Externa" (PCE) and in the areas of higher altitude of the State. The likely reason for this behavior is associated with higher risk of cold and lower solar radiation availability in such areas, as indicated previously.

\section{Final Considerations}

The results of this study emphasized the best sowing periods, for four groups of rice cultivars and three climatic risk levels (20\%, 30\% and 40\%) in the counties that are suitable for irrigated rice cultivation in the State of Rio Grande do Sul. Detailed information about the sowing periods, for all the counties of the State, are available in Steinmetz et al. (2018) and in governmental decree No. 222, of September $4^{\text {th }} 2018$, of the Ministry of Agriculture, Livestock and Food Supply-MAPA (Brasil, 2018a).

It is recommended that for each crop season producers, especially those who intend to rely on the assurances of Proagro, check if the information contained in this publication are consistent with those of the decrees of MAPA, previously indicated. As they are published annually, before the start of the crop season, these decrees may contain changes, and in this situation, the information indicated therein shall prevail.

The conclusion is that the model SimulArroz is appropriate to define the sowing periods of the irrigated rice in the State of Rio Grande do Sul. The main advantages, compared to the previous studies, are the use of grain yield estimates as the main parameter and three levels of climatic 
Figure 3. Sowing periods for the cimatic risk of $40 \%$ and cultivars of groups 1 Very short (a), 2 - Short (b), 3 - Medium (c) and 4 - Long (d) of irrigated rice in the different counties and riceproducing regions of the State of Rio Grande do Sul.
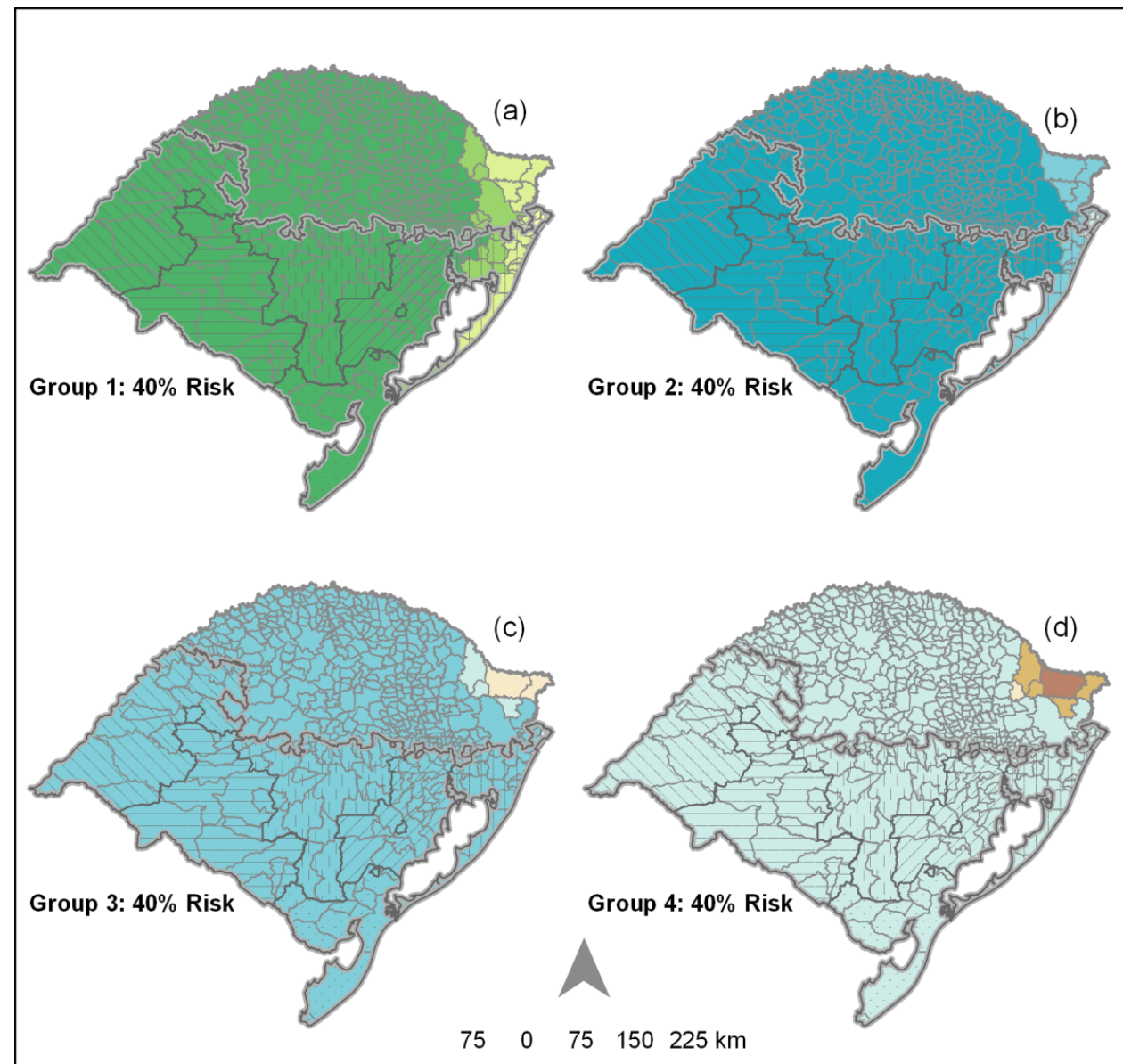

(d)

Sowing periods

01 Sep. - 20 Oct.

01 Sep. - 31 Oct.

01 Sep. -10 Nov.

01 Sep. -20 Nov.

01 Sep. - 30 Nov.

01 Sep. - 10 Dec
75

\begin{tabular}{l}
11 Sep. - 10 Oct. \\
11 Sep. - 31 Oct. \\
$\square 11$ Sep. - 10 Nov. \\
$\square 11$ Sep. - 20 Nov. \\
\hline 11 Sep. - 30 Nov. \\
11 Sep. - 10 Dec. \\
11 Sep. - 20 Dec.
\end{tabular}

Rice Production Regions (IRGA)

$$
\begin{aligned}
& 1 \text { - Fronteira Oeste } \\
& 2 \text { - Campanha } \\
& 3 \text { - Depressão Central } \\
& 4 \text { - Planície Costeira Interna } \\
& 5 \text { - Planície Costeira Externa } \\
& 6 \text { - Zona Sul }
\end{aligned}
$$

risk $(20,30$ and $40 \%)$ rather than one (20\%).

It is believed that other indicators may also be obtained through the estimates of crop yield, enabling the development of new arrangements of credit and crop insurance, strengthening either governmental or private policies. The innovation in the parameters used favors the diversification of climatic risk protection products offered to rice farmers.

\section{Acknowledgements}

The authors gratefully acknowledge the institutions involved in this work, as the State Rice Institute (IRGA) and Embrapa Research Centers (Temperate Climate, Agriculture Informatics and Rice and Beans). Special thanks are addressed to the Federal University of Santa Maria (UFSM) for allowing the use of the crop model SimulAr- roz. This work was supported by EMBRAPA (grants number 02.1306.015.00.04.01) and by the Ministry of Agriculture, Livestock and Food Supply-MAPA (grants number: TED 001/Embrapa/ZARC 2018-SIAFI 692.855).

\section{References}

AMARAL, T. A.; ANDRADE, C. de L. T. de; ALVES, M. E. B.; SILVA, D. F. Applying csm-ceres-maize to define a sowing window for irrigated maize crop - The riacho's farm case study. Ambi-Agua, Taubaté, v. 6, n. 2, p. 38-53, 2011.

BRASIL. Ministério da Agricultura, Pecuária e Abastecimento. Secretaria de Política Agrícola. Instrução Normativa nº 2, de 9 de outubro de 2008. Define as características dos solos tipos 1, 2 e 3 para fins de Zoneamento Agrícola de Risco Climático. Diário Oficial da União. Brasília, 10 out. 2008. Seção 1, n. 197, p. 71.

BRASIL. Casa Civil da Presidência da República. Lei no 12.651, de 25 de maio de 2012. Trata sobre a proteção da vegetação nativa. Diário Oficial da União, Atos do Poder Legislativo, Brasília, DF, 28 mai. 2012. Seção 1, n. 102, p. 01-08. 
BRASIL. Ministério da Agricultura, Pecuária e Abastecimento. Secretaria de Política Agrícola. Portaria no 222, de 4 de setembro de 2018a, Zoneamento Agrícola de Risco Climático para a cultura do arroz irrigado no Estado do Rio Grande do Sul, ano-safra 2018/2019. Diário Oficial da União, Brasília, 5 set. 2018. Seção 1, n. 172, p. 06-16.

BRASIL. Ministério da Agricultura, Pecuária e Abastecimento. Secretaria de Política Agrícola. SISZARC - Sistema de Zoneamento Agrícola de Risco Climático. Relatório de Relação de Cultivares. Disponível em: <http://sistemasweb.agricultura.gov.br/siszarc/ gerarRelatorioRelacaoCultivares.action?sgJAASAplicacaoPrincipal=sisza rc>. Acesso em: 30 nov. 2018 b.

CONAB. Acompanhamento da safra brasileira - grãos. v. 5 - Safra 2017/2018 - n. 12 - Décimo segundo levantamento - Setembro 2018. Disponível em: <https://www.conab.gov.br/info-agro/safras/graos>. Acesso em: 8 out. 2018.

CRUZ, R. P. da. O frio e a cultura do arroz. Lavoura Arrozeira, Porto Alegre, v. 54, n. 440, p. 40-43, nov. 2006.

MARIOT, C. H. P.; MENEZES, V. G.; LIMA, A. L.; RAMÍREZ, H. V.; NEVES, G. Influência da época de semeadura no rendimento de grãos de cultivares de arroz irrigado: safras 2003/04 e 2004/05. In: CONGRESSO BRASILEIRO DE ARROZ IRRIGADO, 4., REUNIÃO DA CULTURA DO ARROZ IRRIGADO, 26., 2005, Santa Maria. Anais. Santa Maria: Universidade Federal de Santa Maria, 2005. p. 251-253.

MARIOT, C. H. P.; MENEZES, V. G.; HERZOG, R. L. da S.; HERNANDES, G. C.; TROJAN, S. da C.; CHAVES, A. da C.; MORRONI, G. S. Influência da época de semeadura no rendimento de grãos de arroz irrigado: safra 2006/07. In: CONGRESSO BRASILEIRO DE ARROZ IRRIGADO, 5.; REUNIÃO DA CULTURA DO ARROZ IRRIGADO, 27., 2007, Pelotas. Anais. Pelotas: Embrapa Clima Temperado, 2007. p. 342-345.

MATSUI, T.; OMASA, K.; HORIE, T. The difference in sterility due to high temperatures during the flowering period among Japonica-rice varieties. Plant Production Science, v. 4, n. 2, p. 90-93, 2001.

MENEZES, V. G.; RAMÍREZ, H.; LIMA, A.; NEVES, G. Influência da época de semeadura no rendimento de grãos de genótipos de arroz irrigado: safra 2002/03. In: CONGRESSO BRASILEIRO DE ARROZ IRRIGADO, 3; REUNIÃO DA CULTURA DO ARROZ IRRIGADO, 25., 2003, Balneário Camboriú. Anais. Itajaí: EPAGRI, 2003. p. 196-198.

MENEZES, V. G.; ANGHINONI, I.; SILVA, P. R. F. da; MACEDO, V. R. M.; PETRY, C.; GROHS, D. dos S.; FREITAS, T.F. S. de; VALENTE, A. de L. Projeto 10: estratégias de manejo para aumento da produtividade e da sustentabilidade da lavoura de arroz irrigado no RS: avanços e novos desafios. Cachoeirinha: IRGA/Estação Experimental do Arroz, 2012.

MOTA, F. S. da. Disponibilidade de radiação solar e risco de frio no período reprodutivo do arroz irrigado em diferentes regiões do Rio Grande do Sul. Lavoura Arrozeira, Porto Alegre, v. 48, n. 424, p. 8-10, nov./dez. 1995

PAIXÃO, J. de S.; ANDRADE, C. de L. T. de; GARCIA, A. G.; AMARAL, T. A.; STEIDLE NETO, A. J.; MARIN, F. R. An alternative approach to the actual brazilian maize crop zoning. Revista Brasileira de Milho e Sorgo. Sete Lagoas, v. 13, n. 3, p. 347-363, 2014.

PENG, S.; HUANG, J.; SHEEHY, J. E.; LAZA, R. C.; VISPERAS, R. M.; ZHONG, X.; CENTENO, G. S.; KHUSH, G. S.; CASSMAN, K. G. Rice yields decline with higher night temperature from global warming. National Academy of Sciences of the USA, Washington, D. C., v. 101, n. 27, p. 9971-9975, jul. 2004. Disponível em: <www.pnas.org/cgi/doi/10.1073/ pnas.0403720101>. Acesso em: 15 jul. 2004.

POWER/NASA. Prediction of Worldwide Energy Resource. Disponível em: <www.power.larc.nasa.gov/com-common/php/POWER_

AboutAgroclimatology.php>. Acesso em: 5 out. 2018.

PRASAD, P. V. V.; BOOTE, K. J.; ALLEN JR., L. H.; SHEELY, J. E.; THOMAS, J. M. G. Species, ecotype and cultivar differences in spikelet fertility and harvest index of rice in response to high temperatures stress. Field Crop Research, v. 95, p. 398-411, 2006. Disponível em: <www. sciencedirect.com>. Acesso em: 30 out. 2016.

RIBAS, G. G.; STRECK, N. A.; LAGO, I.; ZANON, A. J.; WALDOW, D. A. G.; DUARTE JUNIOR, A. J. ; NASCIMENTO, M. F.; FONTANA, V. Acúmulo de matéria seca e produtividade em híbridos de arroz irrigado simulados com o modelo SimulArroz. Pesquisa Agropecuária Brasileira, v. 51, p. 1907-1917, 2016.
RIBAS, G. G.; STRECK, N. A.; DUARTE JUNIOR, A. J.; NASCIMENTO, M. F.; ZANON, A. J.; SILVA, M. R. Number of leaves and phenology of rice hybrids simulated by the SimulArroz model. Revista Brasileira de Engenharia Agrícola e Ambiental, v. 21, p. 221-226, 2017.

ROSA, H. T.; WALTER, L. C.; STRECK, N. A.; CARLI, C. De.; RIBAS, G. G.; MARCHESAN, E. Simulação do crescimento e produtividade de arroz no Rio Grande do Sul pelo modelo SimulArroz. Revista Brasileira de Engenharia Agrícola e Ambiental, Campina Grande, v. 19, n. 12, p. 1-9, dez. 2015.

ROSSETTI, L. A. Zoneamento agrícola em aplicações de crédito e securidade rural no Brasil: aspectos atuariais e de política agrícola. Revista Brasileira de Agrometeorologia, Passo Fundo, v. 9, n. 3, p. 386-399, dez. 2001.

SLATON, N. A.; LISCOMBE, S. D.; NORMAN, R. J.; GBUR, JR., E. E. Seeding date effect on rice yields in Arkansas and Louisiana. Agronomy Journal, Madison, v. 95, p. 218-223, Jan.-Feb. 2003.

SOSBAI (SOCIEDADE SUL-BRASILEIRA DE ARROZ IRRIGADO). Reunião Técnica da Cultura do Arroz Irrigado (32.: 2018 : Farroupilha, RS). Arroz irrigado: Recomendações técnicas da pesquisa para o Sul do Brasil. Pelotas: SOSBAI, 201. 205 p.

STEINMETZ, S.; ALMEIDA, I. R. de. Caracterização e mapeamento do risco de frio durante o período reprodutivo do arroz irrigado no Estado do Rio Grande do Sul. Pelotas: Embrapa Clima Temperado, 2012. (Embrapa Clima Temperado. Boletim de Pesquisa e Desenvolvimento, 175).

STEINMETZ, S.; CUADRA, S. V.; ALMEIDA, I.R. de; STRECK, N. A.; ZANON, A. J.; RIBAS, G. G.; SILVA, M. R. da; BENEDETTI, R.; CERA, J. C.; SILVA, S. C. da; HEINEMANN, A. B. Periodos de semeadura para o arroz irrigado no Rio Grande do Sul com base na estimativa de produtividade de grãos e em níveis de risco climático. Pelotas: Embrapa Clima Temperado, 2018. 57 p. (Embrapa Clima Temperado. Documentos, 472).

STEINMETZ, S.; CUADRA, S. V.; PEREIRA, C. B.; SANTOS, E. L. dos; ALMEIDA, I. R. de. GD Arroz: Programa baseado em graus-dia como suporte ao planejamento e à tomada de decisão no manejo do arroz irrigado. Pelotas: Embrapa Clima Temperado, 2015. 8 p. (Embrapa Clima Temperado. Circular Técnica, 162).

STEINMETZ, S.; DEIBLER, A. N.; SILVA, J. B. da. Estimativa da produtividade de arroz irrigado em função da radiação solar global e da temperatura mínima do ar. Ciência Rural, Santa Maria, v. 43, n. 2, p. 206-211, fev. 2013.

STEINMETZ, S.; FAGUNDES, P. R. R.; FAGUNDES, P. R. R.; MAGALHAES JUNIOR, A. M. de; SCIVITTARO, W. B.; DEIBLER, A. N.;THEISEN, G. Produtividade de cultivares de arroz irrigado em função da época de semeadura. Pelotas: Embrapa Clima Temperado, 2009. 22 p. (Embrapa Clima Temperado. Boletim de Pesquisa e Desenvolvimento, 111).

STEINMETZ, S.; FAGUNDES, P. R. R.; MARIOT, C. H. P.; WREGE, M. S. MATZENAUER, R.; MALUF, J. R. T.;FERREIRA, J. S. A. Zoneamento agroclimático do arroz irrigado por épocas de semeadura no estado do Rio Grande do Sul (versão 4). Pelotas: Embrapa Clima Temperado, 2007. 34 p. (Embrapa Clima Temperado. Documentos, 199).

STEINMETZ, S.; INFELD, J. A.; MALUF, J. R. T.; SOUZA, P. R. de; BUENO, A $C$. Zoneamento agroclimático da cultura do arroz irrigado no Rio Grande do Sul: recomendação de épocas de semeadura por município. Pelotas:EMBRAPA-CPACT, 1996. 30 p. (EMBRAPA-CPACT. Documentos, 19).

STEINMETZ, S.; MAGALHAES JUNIOR, A. M. de; FAGUNDES, P. R. R.; SCIVITTARO, W. B.; ALMEIDA, I. R. de; REISSER JUNIOR, C.; DEIBLER, A. N.; MATZENAUER, R.; RADIN, B.; PRESTES, S. D.; SILVA, M. F. da. Uso de graus-dia para estimar a data de diferenciação da panícula (DP) de seis subgrupos de cultivares de arroz irrigado visando à adubação nitrogenada em cobertura no Rio Grande do Sul. Pelotas: Embrapa Clima Temperado, 2010. 85 p. (Embrapa Clima Temperado. Boletim de Pesquisa e Desenvolvimento, 121).

STEINMETZ, S.; SILVA, S. C. Início dos estudos sobre zoneamento agrícola de risco climático (ZARC) no Brasil. Santo Antônio de Goiás: Embrapa Arroz e Feijão, 2017. 27 p. (Embrapa Arroz e Feijão. Documentos, 312). 
STEINMETZ, S.; WREGE, M. S.; HERTER, F. G.; REISSER JÚNIOR, C.; FERREIRA, J. S. A.; MATZENAUER, R.; MALUF, J. R. T. Macrozoneamento climático para o arroz irrigado no Rio Grande do Sul. Pelotas: Embrapa Clima Temperado, 2005. 20 p. (Embrapa Clima Temperado. Documentos, 137).

STRECK, N. A.; BOSCO, L. C.; MICHELON, S.; ROSA, H. T.; WALTER, L. C.; PAULA G. M. de; CAMARA, C.; LAGO, I.; MARCOLIN, E. Avaliação da resposta ao fotoperíodo em genótipos de arroz irrigado. Bragantia, Campinas, v. 65, n. 4, p. 533-541, 2006.

TERRES, A. L.; GALLI, J. Efeitos do frio em cultivares de arroz irrigado no Rio Grande do Sul: 1984. In: AMARAL, A. dos S.; RIBEIRO, A. S.; GOMES, A. da S.; MENSCHOY, A. B.; TERRES, A. L. S.; DOMINGUEZ GONZALEZ, B.; ZONTA, E. P.; GASTAL, F. L. da C.; XAVIER, F. E.; CARRICONDE FILHO, J.; GONÇALO, J. F. P.; INFELD, J. A.; PARFITT, J. M.; MARTINS, J. F.; GALLI, J.; VAHL, L. C.; MACHADO, M. O.; SILVEIRA JUNIOR, P.; ANDRADE, V. A. de. Fundamentos para a cultura do arroz irrigado. Campinas: Fundação Cargill; Pelotas: EMBRAPA-CPACT, 1985. Cap. 6, p. 83-94.
URATSUKA, A. Y.; NAKAI, A. M. Ferramenta para carga de tabelas de restrição de janelas de plantio para a aplicação Micura. In: MOSTRA DE ESTAGIÁRIOS E BOLSISTAS DA EMBRAPA INFORMÁTICA AGROPCUÁRIA, 13., 2017, Campinas. Resumos expandidos... Brasília, DF: Embrapa, 2017. p. 10-13.

WREGE, M. S.; STEINMETZ, S.; REISSER JÚNIOR, C.; ALMEIDA, I. R. de. (Ed.). Atlas climático da Região Sul do Brasil: Estados do Paraná, Santa Catarina e Rio Grande do Sul. Pelotas: Embrapa Clima Temperado; Colombo: Embrapa Florestas, 2011. 333 p. il. color.

\section{CITATION}

STEINMETZ, S.; CUADRA, S. V.; ALMEIDA, I. R.; STRECK, N. A.; ZANON, A. J.; RIBAS, G. G.; SILVA, M. R.; RÔMULO PULCINELLI BENEDETTI, JOSSANA CEOLIN CERA, J. C.; SILVA; S. C.; HEINEMANN. A. B Irrigated rice sowing periods based on simulated grain yield. Agrometeoros, Passo Fundo, v.27, n.2, p.377-386, dez 2019. 


\title{
Períodos de semeadura para o arroz irrigado baseado na simulação da produtividade de grãos
}

\author{
Silvio Steinmetz ${ }^{(1)}\left(^{*}\right)$, Santiago Vianna Cuadra ${ }^{1}$, Ivan Rodrigues de Almeida ${ }^{1}$, Nereu Augusto Streck ${ }^{2}$, Alencar Júnior Zanon ${ }^{2}$, \\ Giovana Ghislene Ribas ${ }^{2}$, Michel Rocha da Silva ${ }^{2}$, Rômulo Pulcinelli Benedetti ${ }^{2}$, Jossana Ceolin Cera ${ }^{3}$, Silvando Carlos da Silva ${ }^{4}$ e \\ Alexandre Bryan Heinemann ${ }^{4}$ \\ ${ }^{1}$ Embrapa Clima Temperado. Rodovia BR $392 \mathrm{~km} \mathrm{78,} \mathrm{Cx.} \mathrm{Postal} \mathrm{403,} \mathrm{CEP} \mathrm{96.010-971} \mathrm{Pelotas,} \mathrm{RS.}$ \\ E-mails: silvio.steinmetz@embrapa.br, santiago.cuadra@embrapa.br e ivan.almeida@embrapa.br \\ ${ }^{2}$ Universidade Federal de Santa Maria (UFSM), Departamento de Fitotecnia, Centro de Ciências Rurais (CCR). Avenida Roraima, 1000, Bairro Camobi, CEP \\ 97105-900 Santa Maria, RS. \\ E-mails: nereustreck2@yahoo.com.br, alencarzanon@hotmail.com, giovana.ghisleni@hotmail.com, michelrs@live.com e romuluspb@gmail.com \\ ${ }^{3}$ Instituto Rio Grandense do Arroz (IRGA), Estação Experimental do Arroz (EEA). Avenida Bonifácio Carvalho Bernardes, 1494 - Vila Carlos Antonio Wilk- \\ ens, CEP 94930-030 Cachoeirinha, RS. E-mail: jossana.cera@gmail.com \\ ${ }^{4}$ Embrapa Arroz e Feijão. Rodovia GO 462, km 12, Fazenda Capivara, Zona Rural Caixa Postal 179, CEP 75375-000 Santo Antônio de Goiás, GO. \\ E-mails: silvando.silva@embrapa.br e alexandre.heinemann@embrapa.br \\ ${ }^{(*)}$ Autor para correspondência.
}

\section{INFORMAÇÕES}

\section{História do artigo:}

Recebido em 30 de janeiro de 2019

Aceito em 11 de março de 2020

Termos para indexação:

Oryza sativa L.

modelo de simulação de cultura,

clima

zoneamento de risco

\section{RESUMO}

O objetivo deste trabalho foi estabelecer os períodos de semeadura com menor risco climático para o cultivo do arroz irrigado no Estado do Rio Grande do Sul, utilizando a produtividade de grãos estimada pelo modelo SimulArroz. Dados de produtividade foram normalizados para cada um dos quatro grupos de cultivares, considerando-se os valores de Produtividade Relativa (PRel), calculados em função da Produtividade de Referência (PRef). As PRef consideradas foram iguais ao percentil 80, para as cultivares dos grupos 1 e 2 (de ciclos Muito curto e Curto, respectivamente), e ao percentil 90, para as cultivares dos grupos 3 e 4 (de ciclos Médio e Longo, respectivamente). Os anos de sucesso foram considerados quando os valores de PRel foram iguais ou maiores que $60 \%$ da PRef. Esses anos foram usados para classificar os níveis de risco de $20 \%$ ( $80 \%$ de sucesso), de $30 \%$ (70\% de sucesso) e de $40 \%$ (60\% de sucesso). Os resultados indicaram que o início da semeadura ocorre, dependendo do grupo de cultivares, no dia $1^{\circ}$ de setembro ou 11 de setembro. A data final de semeadura varia com o grupo de cultivares e com o nível de risco envolvido, sendo 20 de dezembro o último dia para o grupo 1 (ciclo Muito curto). Conclui-se que o modelo SimulArroz é apropriado para definir os períodos de semeadura do arroz irrigado no Rio Grande do Sul.
REFERENCIAÇÃO

STEINMETZ, S.; CUADRA, S. V.; ALMEIDA, I. R.; STRECK, N. A.; ZANON, A. J.; RIBAS, G. G.; SILVA, M. R.; RÔMULO PULCINELLI BENEDETTI, JOSSANA CEOLIN CERA, J. C.; SILVA; S. C.; HEINEMANN. A. B. Irrigated rice sowing periods based on simulated grain yield. Agrometeoros, Passo Fundo, v.27, n.2, p.377-386, dez 2019. 